\title{
Correction to: Kadec-Klee property in Musielak-Orlicz function spaces equipped with the Orlicz norm
}

\author{
YunAN CUI AND Li ZHAO
}

To my supervisor, Henryk Hudzik.

\section{Correction to: Aequat. Math. https://doi.org/10.1007/s00010-021-00808-8}

The article Kadec-Klee property in Musielak-Orlicz function spaces equipped with the Orlicz norm, written by Yunan Cui and Li Zhao, was originally published online on 1st June 2021 with Open Access under a "This article is licensed under a Creative Commons Attribution 4.0 International License, which permits use, sharing, adaptation, distribution and reproduction in any medium or format, as long as you give appropriate credit to the original author(s) and the source, provide a link to the Creative Commons licence, and indicate if changes were made. The images or other third party material in this article are included in the article's Creative Commons licence, unless indicated otherwise in a credit line to the material. If material is not included in the article's Creative Commons licence and your intended use is not permitted by statutory regulation or exceeds the permitted use, you will need to obtain permission directly from the copyright holder. To view a copy of this licence, visit http:// creativecommons.org/licenses/by/4.0/". After publication, the author(s) decided to cancel the Open Access. Therefore, the copyright of the article has been changed on 22nd June to (c) Springer Nature Switzerland AG 2021 with all rights reserved.

Publisher's Note Springer Nature remains neutral with regard to jurisdictional claims in published maps and institutional affiliations.

The original article can be found online at https://doi.org/10.1007/s00010-021-00808-8. 
Yunan Cui and Li Zhao

Department of Mathematics

Harbin University of Science and Technology

Harbin 150080

China

e-mail: cuiya@hrbust.edu.cn

Li Zhao

e-mail: 2108983987@qq.com 